Vol. 1, No. 3, 2019

\title{
IMPLEMENTASI METODE K-MEDOIDS CLUSTERING UNTUK MENGETAHUI POLA PEMILIHAN PROGRAM STUDI MAHASIWA BARU TAHUN 2018 DI UNIVERSITAS KANJURUHAN MALANG
}

\author{
Bagus Wira $^{1}$, Alexius Endy Budianto ${ }^{2}$, Anggri Sartika Wiguna ${ }^{3}$ \\ Program Studi Teknik Informatika, Universitas Kanjuruhan $1,2,3$ \\ bgswira@gmail.com ${ }^{1}$,endybudianto@unikama.ac.id ${ }^{2}$, anggrisartikawiguna@unikama.ac.id ${ }^{3}$
}

\begin{abstract}
Abstrak. Setiap tahun Universitas Kanjuruhan Malang menerima hampir 2.000 mahasiswa yang tersebar diberbagai program studi. Oleh karenanya data yang telah ditampung pastinya banyak sekali, dari data tersebut dapat dilihat pola - pola pemilihan program studi berdasarkan nilai tes, asal sekolah, dan program studi. Penelitian ini menggunakan metode K-Medoids agar dapat diketahui pola pemilihan program studi bagi mahasiswa baru. K-Medoids merupakan metode partisional clustering dimana bertujuan untuk menemukan satu set $k$-cluster di antara data yang paling mencirikan objek dalam kumpulan suatu data. Hasil penelitian pengelompokan mahasiswa baru menunjukkan bahwa mahasiswa baru yang berasal dari SMA/SMK dengan nilai ujian diatas 70 mengambil jurusan TI, sedangkan mahasiswa baru yang berasal dari SMK dengan nilai ujian dibawah 70 dan SMA dengan nilai ujian dibawah 50 mengambil jurusan SI, dan sisanya mengambil jurusan NON TI/SI. Kualiatas cluster yang dihasilkan berdasarkan proses pengujian yang dilakukan didapatkan hasil nilai Silhouette Coefficient terbaik yaitu 0.690754 dengan jumlah cluster sebanyak tiga dan jumlah data sebanyak 15 .
\end{abstract}

Kata Kunci: Clustering, K-Medoids, Silhoutte Coeffcient, Pola Pemilhan Program Studi.

\section{PENDAHULUAN}

Banyaknya data yang tersimpan dalam database suatu universitas terkadang tidak dapat termanfaatkan dengan baik selain sebagai kebutuhan administrasi, padahal setiap tahun terdapat penambahan data akibat penerimaan mahasiswa baru di lingkungan perguruan tinggi. Proses penerimaan mahasiswa baru menghasilkan data yang berlimpah melingkupi data pribadi mahasiswa tersebut, hal ini akan terus berlangsung setiap tahun sehingga data yang tersimpan akan semakin banyak dan sangat disayangkan jika data yang ada tidak dimanfaatkan dengan baik sebagai hal positif bagi universitas tersebut.

Sama halnya yang terjadi di lingkungan Universitas Kanjuruhan Malang, setiap tahun menerima hampir 2.000 mahasiswa yang terbagi dalam 17 program studi di enam fakultas untuk program S1. Sementara itu, untuk pasca sarjana ada dua program studi di dua fakultas. Oleh karenanya data yang telah ditampung pastinya banyak sekali, jika data tersebut dimanfaatkan dengan penerapan data mining maka akan dapat dilihat pola - pola pemilihan program studi berdasarkan nilai ujian, asal sekolah, dan prodi.

Mengingat pentingnya pengelompokkan data mahasiswa baru, maka sangat perlu untuk dilakukan penelitian mengenai data mining, penelitian ini akan menggunakan metode $k$-medoids agar dapat diketahui pola pemilihan program studi bagi mahasiswa baru di lingkungan Universitas Kanjuruhan Malang. Sehingga dengan adanya penelitian ini dapat menjadi pengetahuan dan referensi baik bagi pengelola administrasi Universitas Kanjuruhan Malang maupun calon mahasiswa baru. Dari penelitian ini diharapkan dapat diketahui apakah mahasiswa tersebut benar - benar memilih program studi yang masih linear dengan bidang keilmuan yang dipelajari pada 
jenjang pendidikan sebelumnya ataukah terjadi penyimpangan di SMA/SMK terdahulu terhadap pemilihan program studi yang ada di Universitas Kanjuruhan Malang.

\subsection{Data Mining}

Data mining adalah sebuah proses pencarian secara otomatis informasi yang berguna dalam tempat penyimpanan data berukuran besar. Istilah lain yang sering digunakan diantaranya knowledge discovery (mining) in databae (KDD), knowledge extraction, data atau pattern analysis, data archeology, data dredging, information harvesting, dan business intelligence. Teknik data mining digunakan untuk memeriksa basis data berukuran besar sebagai cara untuk menemukan pola yang baru dan serbaguna. Tidak semua pekerjaan pencarian informasi dinyatakan sebagai data mining. Sebagai contoh, pencarian record individual menggunakan database management system atau pencarian halaman we tertentu melalu kueri ke semua search engine adalah pekerjaan pencarian informasi yang erat kaitannya dengan information retrieval. Teknik - teknik data mining dapat digunakan meningkatkan kemampuan sistem - sistem information retrieval.

\subsection{Clustering}

Menurut Larose (2015) clustering merupakan suatu proses pengelompokan record, observasi, atau mengelompokkan kelas yang memiliki kesamaan objek. Perbedaan clustering dengan klasifikasi yaitu tidak adanya variabel target dalam melakukan pengelompokan pada proses clustering. Clustering sering dilakukan sebagai langkah awal dalam proses data mining.

Kualitas hasil clustering sangat bergantung pada metode yang dipakai. Metode clustering juga harus dapat mengukur kemampuannya sendiri dalam usaha untuk menemukan suatu pola tersembunyi pada data yang sedang diteliti. Terdapat berbagai metode yang dapat digunakan untuk mengukur nilai kesamaan antar objek-objek yang dibandingkan, salah satunya ialah dengan Euclidean Distance. Euclidean distance menghitung jarak dua buah point dengan mengetahui nilai dari masing-masing atribut pada kedua poin tersebut. Berikut formula yang digunakan untuk menghitung jarak dengan Euclidean Distance:

$$
\operatorname{Distance}(p, q)=\left(\sum_{k}^{n} \mu k|P k-q k| r\right) 1 / r
$$

Keterangan:

$\mathrm{n} \quad=$ Jumlah record data

$\mathrm{k} \quad=$ Urutan field data

$\mathrm{r} \quad$ = pangkat 2

$\mu \mathrm{k}=$ Bobot field yang diberikan $u s e r$

\subsection{K-Medoids Algorithm}

\subsubsection{Clustering K-Medoids}

Algoritma K-Medoids atau sering disebut juga dengan algoritma PAM (Partitioning Around Medoid) dikembangkan oleh Leonard Kaufman dan Peter J. Rousseeuw, dimana merupakan algoritma yang mirip dengan k-means karena kedua algoritma ini partitional yang memecah dataset menjadi kelompok - kelompok. Perbedaan dari algoritma $k$-means dengan algoritma $K$ Medoids terletak pada penentuan pusat cluster, dimana algoritma $k$-means menggunakan nilai rata - rata (means) dari setiap cluster sebagai pusat cluster dan algoritma K-Medoids menggunakan objek data sebagai perwakilan (medoids) sebagai pusat cluster (Kaur, dkk., 2014). Algoritma $K$ Medoids digunakan untuk mengatasi kelemahan dari algoritma k-means yang sangat sensitif terhadap pencilan (outlier) karena objek - objek ini sangat jauh letaknya/karakteristiknya dari 
mayoritas data lainnya, sehingga jika dimasukkan ke suatu cluster data semacam ini bisa mendistorsi nilai rata-rata (mean) cluster tersebut.

\subsubsection{Langkah Clustering K-Medoids}

Algoritma K-Medoids merupakan teknik partisi klasik dari clustering yang melakukan klasterisasi dataset objek $n$ ke dalam $k$ cluster yang dikenal sebagai a priori (Abhishek \& Purnima, 2013). Algoritma ini beroperasi pada prinsip untuk meminimalkan jumlah kesamaan antara setiap objek dan titik referensi yang sesuai. Algoritma $\mathrm{K}$-Medoids dapat dilakukan dengan langkah - langkah sebagai berikut (Bhat, 2014):

a. Inisialisasi pusat cluster sebanyak $k$ (jumlah cluster).

b. Hitung setiap objek ke cluster terdekat menggunakan persamaan ukuran jarak Euclidian Distance. Perhitungan Euclidian Distance menggunakan persamaan (2.1)

c. Setelah menghitung jarak Euclidian Distance, inisialisasikan pusat cluster baru secara acak pada masing - masing objek sebagai kandidat non medoids.

d. Hitung jarak setiap objek yang berada pada masing - masing cluster dengan kandidat non medoids.

e. Hitung total simpangan $(S)$ dengan menghitung total distance baru - total distance lama. Jika $S<0$ maka tukar objek dengan data cluster non medoids untuk membentuk sekumpulan $k$ objek baru sebagai medoids.

f. Ulangi langkah $\mathrm{c}$-e hingga tidak terjadi perubahan pada medoid, sehingga di dapatkan cluster beserta anggota cluster masing - masing.

\subsection{Silhouette Coefficient}

Silhouette Coefficient merupakan sebuah metode yang digunakan untuk melihat kualitas dan kekuatan cluster, seberapa baik suatu objek ditempatkan dalam suatu cluster. Metode Silhouette Coefficient ini merupakan sebuah metode gabungan dari metode cohesion dan metode separation. Metode cohesion adalah sebuah ukuran seberapa dekat relasi antara objek dalam sebuah cluster. Sedangkan metode separation adalah sebuah ukuran seberapa jauh atau terpisah sebuah cluster dengan cluster yang lainnya.

Tahapan perhitungan Silhouette Coefficient antara lain [Handoyo, dkk., 2014]:

1. Hitung jarak rata-rata dari suatu objek misalkan objek ke- $i$ dengan semua objek lain yang berada di dalam satu cluster.

$$
a(i)=\frac{1}{[A]-1} \sum j \in_{A, j \neq i} d(i, j)
$$

2. Hitung rata-rata jarak dari objek ke- $i$ tersebut dengan semua objek pada cluster lainnya, kemudian ambillah nilai terkecilnya.

$$
d(i, C)=\frac{1}{[A]} \sum j \in C \quad d(i, j)
$$

3. Nilai Silhouette Coefficient nya adalah:

Jumlah $s(i)$ diperoleh dengan menggabungkan $a(i)$ dan $b(i)$ :

Sehingga dapat dirumuskan:

$$
\mathrm{s} \begin{cases}1-a(i) / b(i) & \text { if } a(i)<b(i), \\ 0 & \text { if } a(i)=b(i) \\ b(i) / a(i)-1 & \text { if } a(i)>b(i)\end{cases}
$$




$$
s(i)=\frac{b(i)-a(i)}{\max (a(i), b(i))}
$$

Nilai hasil perhitungan dengan menggunakan metode Silhouette Coefficient terletak pada kisaran antara nilai -1 hingga 1. Nilai rata-rata Silhouette Coefficient dari setiap objek dalam suatu cluster merupakan suatu ukuran yang menunjukkan seberapa dekat kemiripan data dikelompokkan didalam satu cluster tersebut. Semakin nilai rata-rata Silhouette Coefficient mendekati nilai 1, maka semakin baik pengelompokan data di dalam satu cluster. Sebaliknya jika nilai rata-rata Silhouette Coefficient mendekati -1, maka semakin buruk pengelompokan data di dalam satu cluster. Berikut kriteria pengukuran nilai Silhouette Coefficient [Rousseeuw, 1987].

Tabel 1. Ukuran Nilai Silhouette Coefficient

\begin{tabular}{ll}
\hline Silhouette Coefficient & Interpretasi yang diusulkan \\
\hline $0.7<\mathrm{SC} \leq 1.0$ & Stronge Structure \\
\hline $0.5<\mathrm{SC} \leq 0.7$ & Mediun Structure \\
\hline $0.25<\mathrm{SC} \leq 0.5$ & Weak Structure \\
\hline $\mathrm{SC} \leq 0.25$ & No Structure
\end{tabular}

Berikut merupakan gambar ilustrasi dari silhouette coefficient:

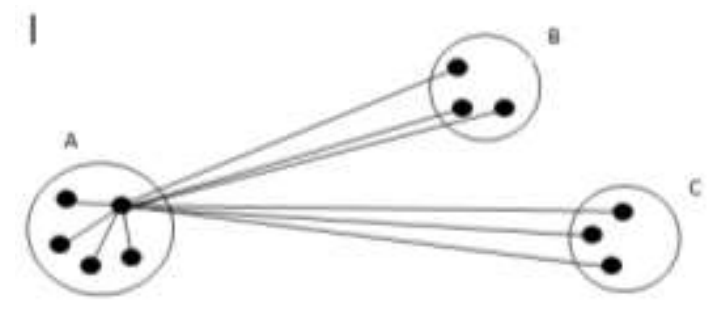

Gambar 1. Ilustrasi elemen-elemen yang termasuk dalam perhitungan s(i), dimana objek data ke-i termasuk dalam cluster A (Rousseeuw, 1987)

\section{METODE PENELITIAN}

Metode penelitian menjelaskan langkah - langkah yang akan digunakan serta perancangan dalam melakukan implementasi. Metode K-Medoids clustering untuk pengelompokkan data pola pemilihan program studi mahasiswa baru.

Gambar 3.1 menunjukkan alur dari diagram blok metodologi penelitian dimana pada setiap tahapnya memiliki fungsi serta tugas masing - masing yang saling berkaitan pada satu tahapan dengan tahapan berikutnya.

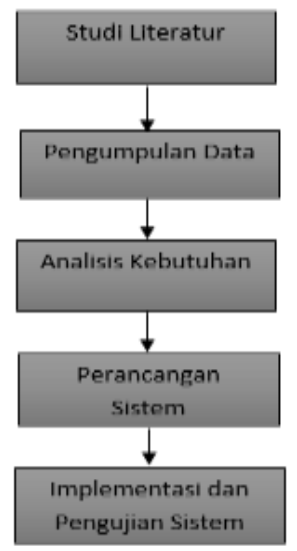

Gambar 2. Diagram Blok Metode Penelitian 


\subsection{Studi Literatur}

Dalam penelitian ini, studi literatur berfungsi untuk menjelaskan dasar teori dari berbagai sumber acuan yang digunakan dalam penulisan penelitian clustering untuk pengelompokkan data mahasiswa baru menggunakan metode $K$-Medoids Clustering

\subsection{Pengumpulan Data}

Pada tahap ini dilakukan pengumpulan data dari objek yang akan diteliti dimana data ini diperoleh dari Universitas Kanjuruhan Malang. Data yang digunakan memiliki 3 variabel yang berisikan nilai ujian tes masuk kuliah, asal sekolah, dan program studi yang dipilih.

\subsection{Analisis Kebutuhan}

Analisis kebutuhan dilakukan untuk menentukan kebutuhan apa saja yang dibutuhkan dalam penelitian yang akan dilakukan, kebutuhan ini akan digunakan dalam proses membangun perangkat lunak.

\subsection{Perancangan Sistem}

Pada tahap perancangan sistem ini terdapat beberapa deskripsi sistem yang akan dibuat secara umum yaitu perancangan aplikasi, manualisasi, rancang antar muka aplikasi, pengujian dan analisis.

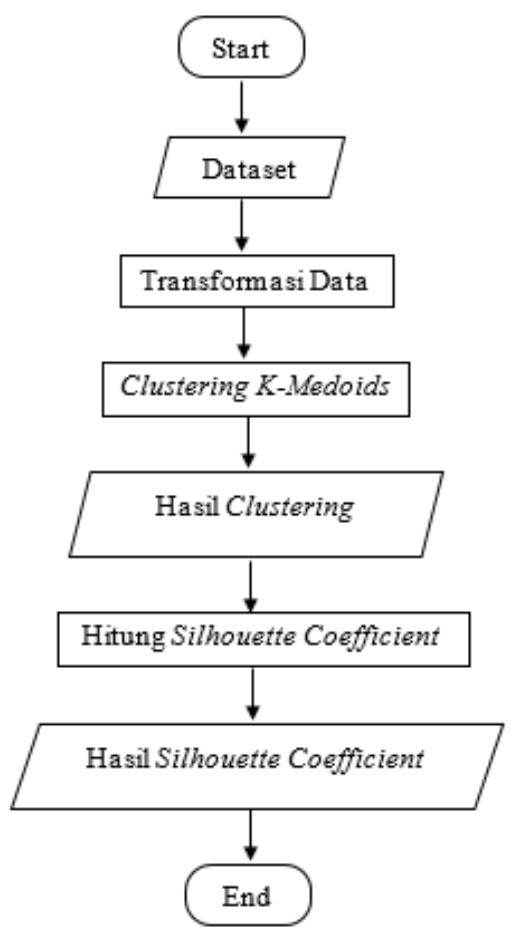

Gambar 2. Flowchart Perancangan Perangkat Lunak

Berikut merupakan penjelasan tahapan - tahapan dalam proses perancangan perangkat lunak pada penerapan metode $K$-Medoids Clustering untuk pengelompokan data mahasiswa baru:

a. Melakukan input data berupa data mahasiswa baru.

b. Melakukan transformasi data yang telah di inputkan untuk proses perhitungan selanjutnya.

c. Melakukan proses klasterisasi dengan menggunakan algoritma $K$-Medoids.

d. Melakukan proses validasi terhadap kualitas cluster dengan menghitung nilai Silhoutte Coefficient 
e. Menampilkan keluaran hasil dari clustering dengan kualitas cluster yang dapat dilihat dari nilai Silhoutte Coefficient yang dihasilkan.

Secara garis besar proses metode K-Medoids ditunjukkan pada diagram alir pada Gambar.3.

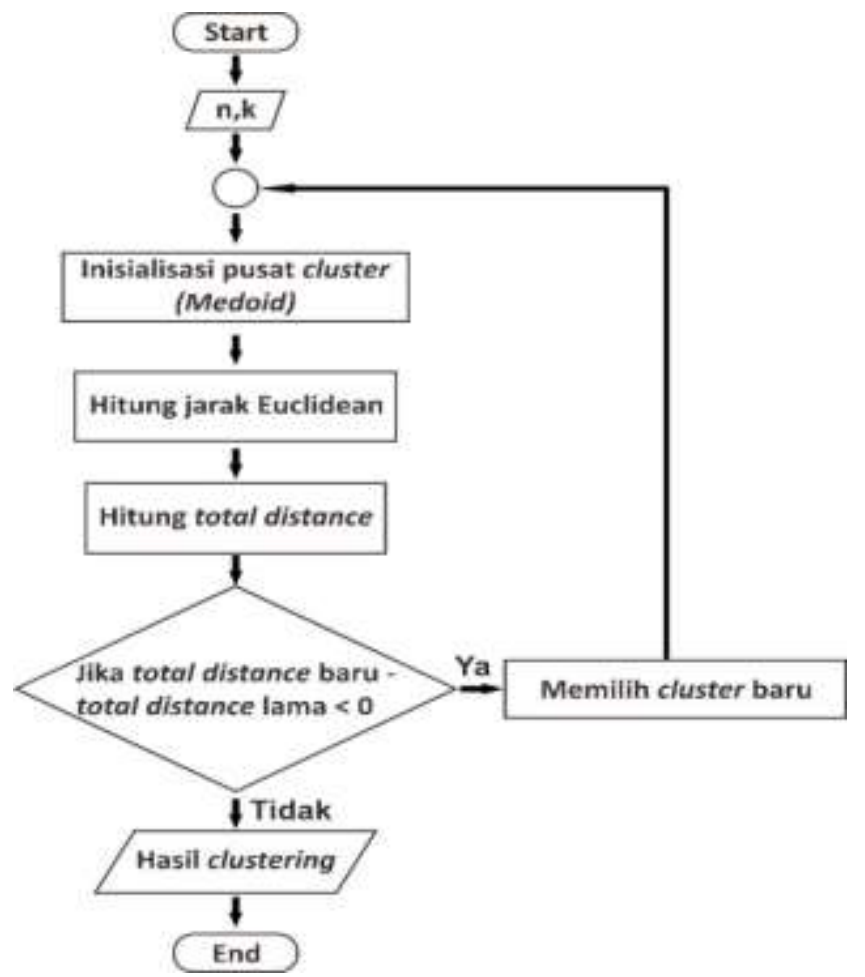

Gambar 3. Diagram Alir Proses K-Medoids Clustering

\subsection{Implementasi dan Pengujian Sistem}

Dalam hal ini implementasi merupakan tahap dimana sistem siap dioperasikan pada keadaaan yang sebenarnya, sehingga akan diketahui apakah sistem yang dibuat benar-benar dapat menghasilkan tujuan yang ingin dicapai. Sistem ini dibangun dengan berbasis web dengan menggunakan bahasa pemrograman PHP. Pada pengujian perangkat lunak akan dilakukan pengujian terhadap jumlah cluster dan jumlah data terbaik. Teknik pengujian ini dilakukan menggunakan metode black box dengan mengevaluasi cara kerja sistem yang telah dibuat.

\section{HASIL DAN PEMBAHASAN}

\subsection{Analisis Data}

Secara umum, sistem yang akan dibangun dalam penelitian ini adalah sebuah sistem dengan fungsi utama untuk melakukan pengelompokkan calon mahasiswa baru. Data yang digunakan untuk penelitian merupakan data yang diperoleh dari Penerimaan Mahasiswa Baru (PMB) tahun 2018 di Universitas Kanjuruhan Malang. Adapun pengelompokkan data tersebut digunakan langkah - langkah sebagai berikut:

\section{Sumber Data}

Sumber data dalam penelitian ini langsung diambil dari Universitas Kanjuruhan Malang dimana data tersebut merupakan data sekunder yang terdiri atas data mahasiswa baru tahun ajaran 2018 - 2019 sebanyak 15 data yang sudah di sorting. 


\section{Transformasi Data}

Pada tahap ini dilakukan proses transformasi data tujuannya adalah untuk menyemakan skala atribut data dalam range yang lebih spesifik, sehingga data dapat diolah dengan mudah menggunakan metode $K$-Medoids Clustering. Variabel yang dipilih pada data pendaftaran calon mahasiswa baru yaitu nilai ujian, asal sekolah, dan program studi yang dipilih. Untuk variabel nilai ujian dikelompokkan menjadi 3 kelompok, yang pertama untuk nilai ujian dengan rata - rata $<=50$ di transformasikan dengan nilai $1,>50$ dan data $<=70$ di transformasikan dengan nilai 2 dan $>70$ di transformasikan dengan nilai 3. Untuk variabel asal sekolah di kelompokkan menjadi 2 kelompok yang pertama untuk asal sekolah SMA di transformasikan dengan nilai 1 dan asal sekolah SMK di transformasikan dengan nilai 2.

\section{Pengolahan Data}

Setelah proses transformasi langkah selanjutnya adalah proses pengolahan data menggunakan metode K-Medoids Clustering. Tahapan proses metode K-Medoids Clustering adalah sebagai berikut :

a. Ditentukam $k$ (jumlah cluster) dari $n$ objek adalah 3

b. Tentukan cluster awal sebagai medoid dengan asumsi seperti pada Tabel 4.1 berikut

Tabel 2. Inisialasisasi medoids

\begin{tabular}{lllll}
\hline Nama & Keterangan & $x$ & $y$ & $z$ \\
\hline C1 & $\begin{array}{l}\text { Diambil data ke-6 sebagai } \\
\text { pusat cluster ke-1 }\end{array}$ & 1 & 2 & 3 \\
C2 & $\begin{array}{l}\text { Diambil data ke-8 sebagai } \\
\text { pusat cluster ke-2 }\end{array}$ & 2 & 1 & 1 \\
C3 & $\begin{array}{l}\text { Diambil data ke-14 sebagai } \\
\text { pusat cluster ke-3 }\end{array}$ & 1 & 2 & 1 \\
\hline
\end{tabular}

c. Tempatkan objek - objek non medoids ke dalam cluster yang paling dekat dengan medoids berdasarkan jarak Euclidean. Berikut contoh perhitungan jarak pada data ke 1:

$$
\begin{gathered}
d\left(x_{1} c_{1}\right)=\sqrt{(3-1)^{2}+(2-2)^{2}+(1-3)^{2}}=2,828427 \\
d\left(x_{1} \mathrm{c}_{2}\right)=\sqrt{(3-2)^{2}+(2-1)^{2}+(1-1)^{2}}=1,414214 \\
d\left(x_{1} \mathrm{c}_{3}\right)=\sqrt{(3-1)^{2}+(2-2)^{2}+(1-1)^{2}}=2
\end{gathered}
$$

Cara yang sama dapat dilakukan untuk perhitungan jarak data ke-2 sampai data ke-15, sehingga nanti hasil keseluruhannya datanya akan diperoleh seperti pada tabel 4.2 berikut. 
Tabel 3. Hasil perhitungan jarak ke setiap medoids

\begin{tabular}{|c|c|c|c|c|}
\hline Data ke if & $c_{1}$ & $C_{2}$ & $\mathrm{C}_{\pi}$ & Jarak \\
\hline 1 & 2,828 & 1.414 & 2 & 2 \\
\hline 2 & 2 & 2,449 & 2,828 & 1 \\
\hline 3 & 2 & 1.414 & 0 & 3 \\
\hline 4 & 2,449 & 1,414 & 2,449 & 2 \\
\hline 5 & 2,449 & 1,414 & 2,449 & 2 \\
\hline 6 & 0 & 2,449 & 2 & 1 \\
\hline 7 & 1 & 2,236 & 2,236 & 1 \\
\hline 8 & 2,449 & 0 & 1,414 & 2 \\
\hline 9 & 2,236 & 1.732 & 2736 & 2 \\
\hline 10 & 3 & 1 & 2.236 & 2 \\
\hline 11 & 1 & 2,236 & 2,236 & 1 \\
\hline 12 & 2,449 & 0 & 1.414 & 2 \\
\hline 13 & 2,236 & 1 & 1 & 3 \\
\hline 14 & 2 & 1,414 & 0 & 3 \\
\hline 15 & 1 & 1.732 & 1 & 3 \\
\hline JUMIAH & 29,09852 & 21,90628 & 25,50011 & \\
\hline
\end{tabular}

d. Setelah itu, tentukan objek non medoid dengan asumsi sebagai berikut.

Tabel 4. Inisialisasi non medoids

\begin{tabular}{lllll}
\hline Nama & Keterangan & $x$ & $y$ & $z$ \\
\hline D1 & $\begin{array}{l}\text { Diambil data ke-5 sebagai pusat } \\
\text { cluster ke-1 }\end{array}$ & 3 & 1 & 2 \\
D2 & $\begin{array}{l}\text { Diambil data ke-11 sebagai pusat } \\
\text { cluster ke-2 }\end{array}$ & 1 & 1 & 3 \\
D3 & $\begin{array}{l}\text { Diambil data ke-13 sebagai pusat } \\
\text { cluster ke-3 }\end{array}$ & 2 & 2 & 1
\end{tabular}

e. Ulangi langkah c untuk objek non medoids

$$
\begin{gathered}
d\left(x_{1} c_{1}\right)=\sqrt{(3-3)^{2}+(2-1)^{2}+(1-1)^{2}}=1,414214 \\
d\left(x_{1} c_{2}\right)=\sqrt{(3-1)^{2}+(2-1)^{2}+(1-2)^{2}}=3 \\
d\left(x_{1} c_{3}\right)=\sqrt{(3-2)^{2}+(2-2)^{2}+(1-1)^{2}}=1
\end{gathered}
$$

f. Sehingga hasilnya diperoleh seperti pada tabel 4.4 berikut. 
Tabel 5. Hasil perhitungan jarak ke setiap non medoids

\begin{tabular}{|c|c|c|c|c|}
\hline Data ke f & $\mathrm{C}_{1}$ & $\mathrm{C}_{2}$ & $\mathrm{C}_{3}$ & Jarak \\
\hline 1 & 1,414 & 3 & 1 & 3 \\
\hline 2 & 1,414 & 2,236 & 2,236 & 1 \\
\hline 3 & 2,449 & 2,236 & 1 & 3 \\
\hline 4 & 0 & 2,236 & 1,732 & 1 \\
\hline 5 & 0 & 2,236 & 1,732 & 1 \\
\hline 6 & 2.449 & 1 & 2,236 & 2 \\
\hline 7 & 1,732 & 1,414 & 2 & 2 \\
\hline 8 & 1,414 & 2,236 & 1 & 3 \\
\hline 9 & 1 & 2,449 & 1,414 & 1 \\
\hline 10 & 1 & 2,828 & 1,414 & 1 \\
\hline 11 & 2,236 & 0 & 2.449 & 2 \\
\hline 12 & 1,414 & 2,236 & 1 & 3 \\
\hline 13 & 1,732 & 2,449 & 0 & 3 \\
\hline 14 & 2,244 & 2,236 & 1 & 3 \\
\hline 15 & 2,236 & 1,414 & 1,414 & 2 \\
\hline JUMLAH & 22,94156 & 30,20831 & 21,62837 & \\
\hline Total & & 74,77824 & & \\
\hline
\end{tabular}

g. Hitung total simpangan $(S)$ dengan menghitung total distance baru - total distance lama. Jika $S<0$ maka tukar objek dengan data cluster untuk membentuk sekumpulan $k$ objek baru sebagai medoid (Setyawati, 2017).

$S=$ total distance baru - total distance lama

$$
S=76,79409-74,77824=-
$$

h. Karena nilai $S<0$ maka proses pengklasteran dihentikan. Sehingga objek non medoids dijadikan sebagai medoid baru.

i. Sehingga cluster yang di dapatkan seperti pada tabel 4.5.

Tabel 6. Hasil pengclusteran mahasiswa baru dengan k-medoids

\begin{tabular}{ccccc}
\hline & & & & Cluster yang \\
Data ke $i$ & Niai Ujian (I) & Asal Sekolah (v) & Prodi (z) & dilkuti \\
\hline 1 & 75 & SMK & TI & 3 \\
2 & $\$ 8$ & SMK & NON & 1 \\
3 & 44,5 & SMK & II & 3 \\
4 & 72 & SMA & SI & 1 \\
5 & 78 & SMA & SI & 1 \\
6 & 35,4 & SMK & NON & 2 \\
7 & 66,6 & SMK & NON & 2 \\
8 & 56,5 & SMA & TI & 3 \\
9 & 82,1 & SMK & SI & 1 \\
10 & 87 & SMA & TI & 1 \\
11 & 27,3 & SMA & NON & 2 \\
12 & 55 & SMA & TI & 3 \\
13 & 66 & SMK & TI & 3 \\
14 & 32 & SMK & TI & 3 \\
15 & 49,2 & SMK & SI & 2 \\
\hline
\end{tabular}


j. Setelah mendapatkan hasil cluster akhir, hitung nilai average dissimilarity (ai) untuk evaluasi dengan metode silhouette coefficient. Perhitungan $a(i)$ menggunakan persamaan (2.2)

$$
\begin{gathered}
a(i)=\sqrt{(1-1,414214)^{2}}=\sqrt{0,171573}=0,414214 \\
a(i)=\sqrt{(1-0)^{2}}=\sqrt{1}=1 \\
a(i)=\sqrt{(1-0)^{2}}=\sqrt{1}=1 \\
a(i)=\sqrt{(1-1)^{2}}=\sqrt{0}=0 \\
a(i)=\sqrt{(1-1)^{2}}=\sqrt{0}=0 \\
=(0,41424+1+1+0+0) / 5=0,482843
\end{gathered}
$$

k. Lalu hitung nilai lowest average dissimilarity (bi). Perhitungan $b(i)$ menggunakan persamaan (2.3)

$$
\begin{aligned}
& =\sqrt{(0,482843) \rightarrow(1)=\text { distance }} \\
& =(1,473626+2,084022+2+2,084022) / 4=1,910417 \\
& =\sqrt{(1-1)^{2}+(1,48142843) \rightarrow(1)=\text { distance }}=1,473626 \\
& =(1,473626+1,473626+1,473626+1,473626+2+1,473626) / 6=1,561355
\end{aligned}
$$

Nilai minimum antara kedua cluster ialah $b(i)=(1,561355<1,910417)=1,561355$

1. Menghitung nilai silhouette coefficient (si). Perhitungan $s(i)$ menggunakan persamaan (2.4)

$$
s(i)=1-\left(\frac{a i}{b i}\right)=1-\left(\frac{0,482843}{1,561355}\right)=0,690754
$$

m. Karena hasil nilai silhouette coefficient mendekati nilai 1 maka pengelompokan data dalam cluster dinyatakan baik.

Dari perhitungan dan pengelompokan data diatas dapat di ambil kesimpulan, bahwa rata - rata mahasiswa baru yang berasal dari sekolah SMA dan SMK dengan nilai > 70 masuk ke dalam cluster 1, sedangkan untuk mahasiswa baru yang berasal dari SMA dan SMK dengan nilai $<70$ masuk ke dalam cluster 2 dan 3.

Jadi, itu artinya mahasiswa baru yang berasal dari sekolah SMA dan SMK yang nilai ujiannya diatas 70 mengambil jurusan TI, sebaliknya mahasiswa baru yang berasal dari sekolah SMA dan SMK yang nilai ujiannya dibawah 70 mengambil jurusan SI atau diluar SI dan TI. 


\subsection{Rancangan Interface Program}

Di dalam sebuah membangun sistem tentunya sebuah rancangan sangat diperlukan agar saat proses pembuatannya dapat di mengerti dengan mudah.

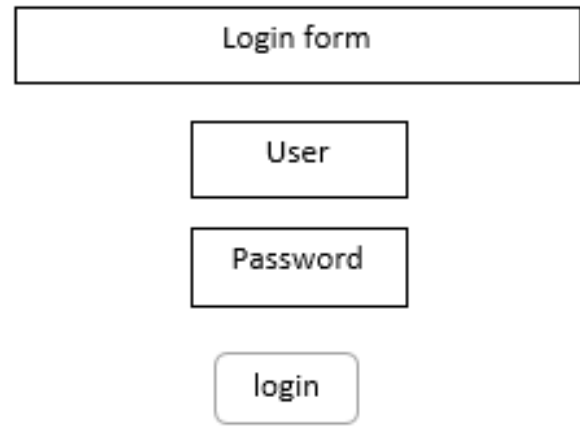

Gambar 4. Rancangan interface login

Digambar perancangan diatas setelah admin melakukan login, akan langsung masuk ke tampilan utama.

Welcome, Admin

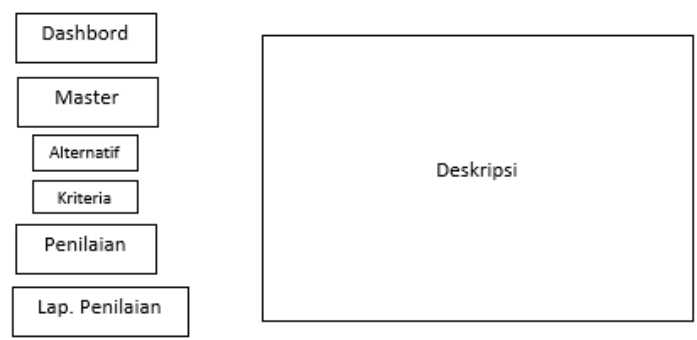

Gambar 5. Tampilan utama

Pada perancangan tampilan utama, admin akan menginput data pada menu master dan memilih sub menu alternatif. Untuk sub menu kriteria nantinya akan berisikan tentang variabel pada pemilihan program studi, mulai dari nilai ujian, asal sekolah, dan prodi yang dipilih.

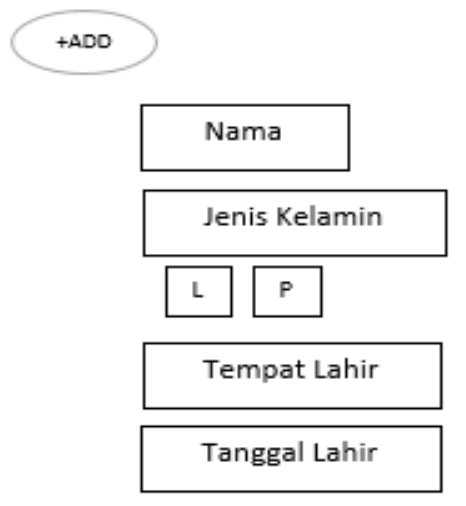

Gambar 6. Rancangan input data

Diperancangan ini nantinya berfungsi untuk menginputkan data mahasiswa baru berdasarkan hasil penelitian di Universitas Kanjuruhan Malang. 


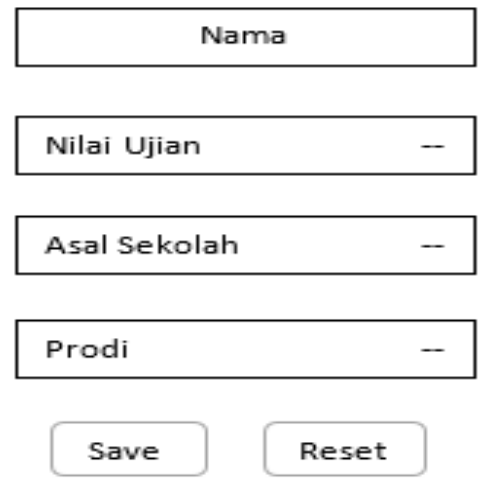

Gambar 7. Rancangan penilaian

Pada perancangan menu penilaian ini nantinya akan di inputkan variabel yang akan di hitung berdasarkan data mahasiswa baru yakni nilai ujian, asal sekolah, dan prodi, kemudian dilakukan perhitungan secara otomatis menggunakan metode $k$-medoids clustering.

\subsection{Implementasi dan Pengujian}

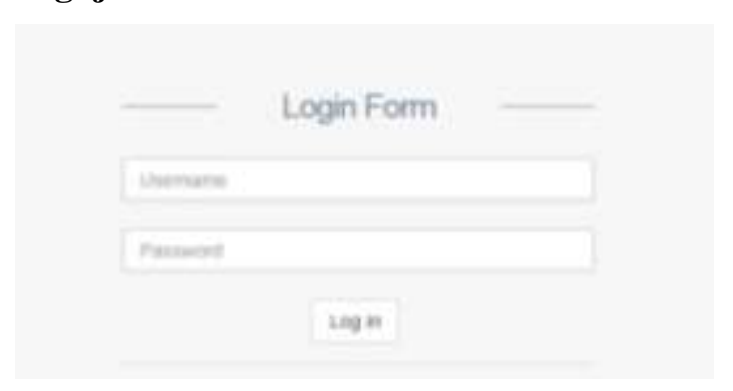

Gambar 8. Tampilan awal

Tabel 7. Deskripsi pengujian tampilan awal

\begin{tabular}{lllll}
\hline Kebutuhan & Skenario & $\begin{array}{l}\text { Hasil yang di } \\
\text { harapkan }\end{array}$ & $\begin{array}{l}\text { Hasil } \\
\text { pengamatan }\end{array}$ & $\begin{array}{l}\text { Hasil } \\
\text { pengujian }\end{array}$ \\
\hline $\begin{array}{l}\text { Pengujian } \\
\text { tampilan } \\
\text { awal }\end{array}$ & $\begin{array}{l}\text { Saat admin tidak } \\
\text { menginputkan } \\
\text { password }\end{array}$ & $\begin{array}{l}\text { Harap isi } \\
\text { password } \\
\text { terlebih dahulu }\end{array}$ & Sesuai & Sesuai \\
\cline { 2 - 5 } & $\begin{array}{l}\text { Saat admin tidak } \\
\text { menginputkan } \\
\text { username }\end{array}$ & $\begin{array}{l}\text { Harap isi } \\
\text { username } \\
\text { terlebih dahulu }\end{array}$ & Sesuai & Sesuai \\
& & & \\
\hline
\end{tabular}




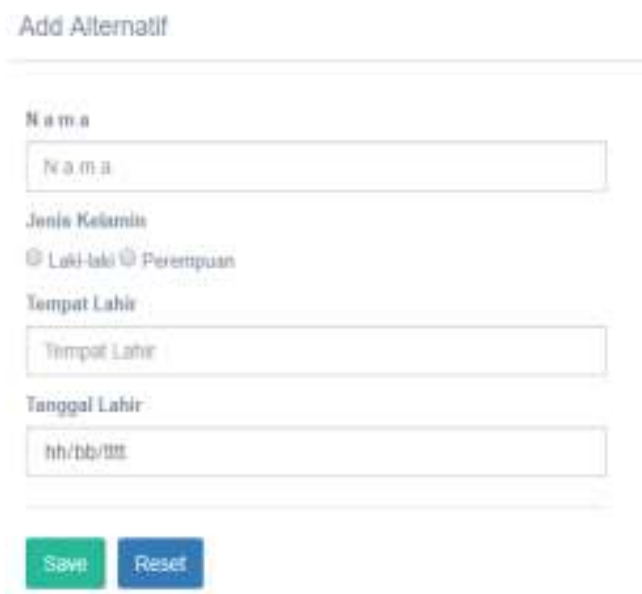

Gambar 9. Tampilan sub menu alternatif untuk inputan data mahasiswa baru

Tabel 8. Deskripsi pengujian sub menu alternatif inputan data

\begin{tabular}{|c|c|c|c|c|c|}
\hline Kebutuhan & Skenario & \multicolumn{2}{|c|}{$\begin{array}{l}\text { Hasil yang di } \\
\text { harapkan }\end{array}$} & $\begin{array}{l}\text { Hasil } \\
\text { pengamat } \\
\text { an }\end{array}$ & $\begin{array}{l}\text { Hasil } \\
\text { pengujian }\end{array}$ \\
\hline \multirow{4}{*}{$\begin{array}{l}\text { Pengujian } \\
\text { interface } \\
\text { pada sub } \\
\text { menu } \\
\text { alternatif } \\
\text { untuk } \\
\text { penginputan } \\
\text { data } \\
\text { mahasiswa } \\
\text { baru }\end{array}$} & $\begin{array}{l}\text { Saat admin tidak } \\
\text { menginputkan } \\
\text { nama mahasiswa } \\
\text { baru }\end{array}$ & $\begin{array}{l}\text { Harap } \\
\text { terlebih } \\
\text { dahulu }\end{array}$ & isi & Sesuai & Sesuai \\
\hline & $\begin{array}{l}\text { Saat admin tidak } \\
\text { menginputkan jenis } \\
\text { kelamin mahasiswa } \\
\text { baru }\end{array}$ & $\begin{array}{l}\text { Harap } \\
\text { terlebih } \\
\text { dahulu }\end{array}$ & isi & Sesuai & Sesuai \\
\hline & $\begin{array}{l}\text { Saat admin tidak } \\
\text { menginputkan } \\
\text { tempat lahir } \\
\text { mahasiswa baru }\end{array}$ & $\begin{array}{l}\text { Harap } \\
\text { terlebih } \\
\text { dahulu }\end{array}$ & isi & Sesuai & Sesuai \\
\hline & $\begin{array}{l}\text { Saat admin tidak } \\
\text { menginputkan } \\
\text { tanggal lahir } \\
\text { mahasiswa baru }\end{array}$ & $\begin{array}{l}\text { Harap } \\
\text { terlebih } \\
\text { dahulu }\end{array}$ & isi & Sesuai & Sesuai \\
\hline
\end{tabular}

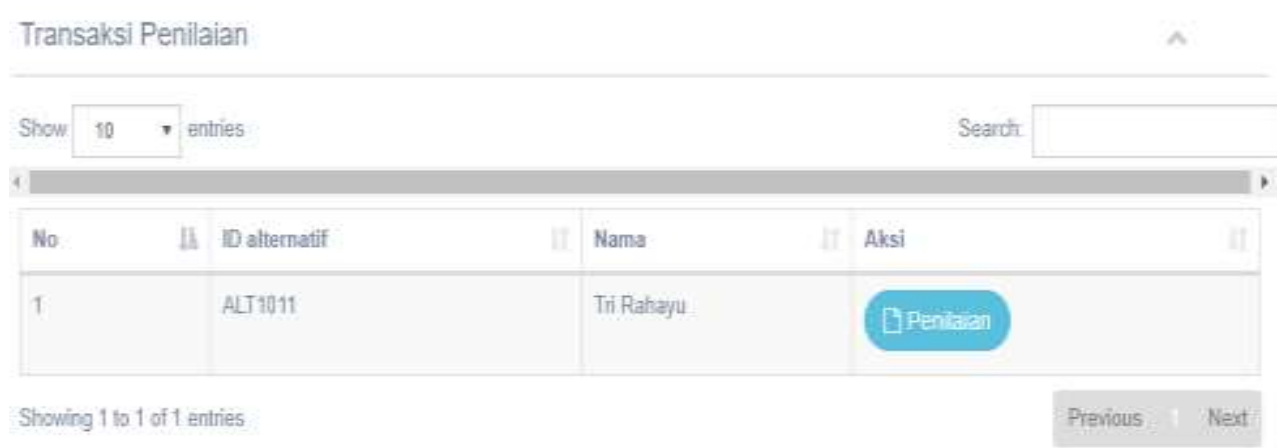

Gambar 10. Tampilan menu penilaian 


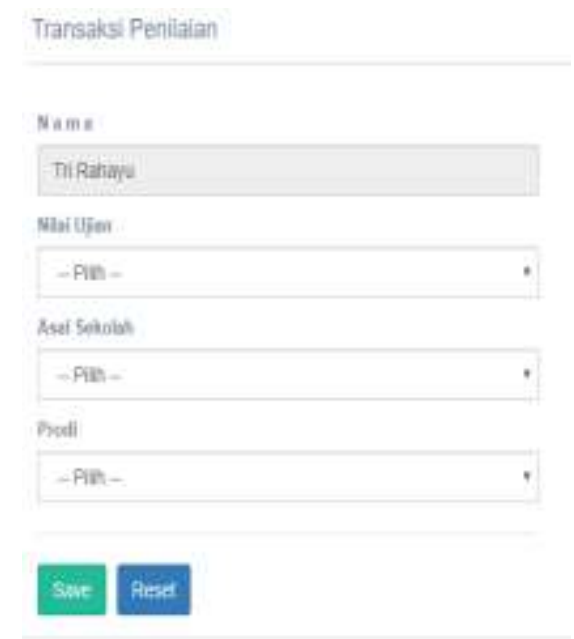

Gambar 11. Tampilan inputan variabel mahasiswa baru pada menu penilaian

Tabel 9. Deskripsi pengujian penilaian

\begin{tabular}{|c|c|c|c|c|c|}
\hline Kebutuhan & Skenario & $\begin{array}{l}\text { Hasil yang } \\
\text { harapkan }\end{array}$ & & $\begin{array}{l}\text { Hasil } \\
\text { pengamatan }\end{array}$ & $\begin{array}{l}\text { Hasil } \\
\text { pengujian }\end{array}$ \\
\hline \multirow{3}{*}{$\begin{array}{l}\text { Pengujian } \\
\text { interface pada } \\
\text { menu penilaian } \\
\text { untuk inputan } \\
\text { nilai varabel } \\
\text { mahasiswa } \\
\text { baru }\end{array}$} & $\begin{array}{l}\text { Saat admin tidak } \\
\text { menginputkan } \\
\text { variabel nilai ujian }\end{array}$ & $\begin{array}{l}\text { Harap } \\
\text { terlebih } \\
\text { dahulu }\end{array}$ & isi & Sesuai & Sesuai \\
\hline & $\begin{array}{l}\text { Saat admin tidak } \\
\text { menginputkan } \\
\text { variabel asal } \\
\text { sekolah }\end{array}$ & $\begin{array}{l}\text { Harap } \\
\text { terlebih } \\
\text { dahulu }\end{array}$ & isi & Sesuai & Sesuai \\
\hline & $\begin{array}{l}\text { Saat admin tidak } \\
\text { menginputkan } \\
\text { variabel prodi }\end{array}$ & $\begin{array}{l}\text { Harap } \\
\text { terlebih } \\
\text { dahulu }\end{array}$ & isi & Sesuai & Sesuai \\
\hline
\end{tabular}

Setelah di inputkan semua variabel pada penilaian, maka akan langsung menghitung secara otomatis nilai variabel yang di inputkan menggunakan metode K-Medoids Clustering, hasilnya akan tampak seperti gambar 4.18

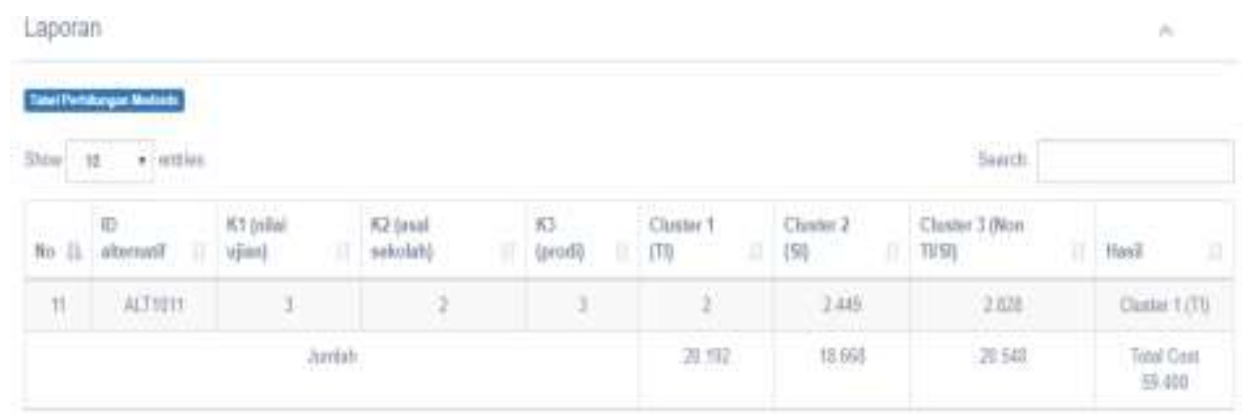

Gambar 12. Tampilan menu laporan penlaian

\section{PENUTUP}

Berdasarkan hasil penelitian yang telah dilakukan dan dibahas pada bab tiga dan empat, dapat diambil kesimpulan sebagai berikut:

\section{Kesimpulan}

Berdasarkan hasil penelitian yang telah dilakukan dapat diambil kesimpulan sebagai berikut: 
1. Algoritma $K$-Medoids dapat di implementasikan untuk proses pola pemilihan program studi mahasiswa baru sesuai dengan tahapan - tahapan perhitungan K-Medoids Clustering.

2. Pengelompokan mahasiswa baru menggunakan metode $K$-Medoids Clustering menunjukkan bahwa mahasiswa baru yang berasal dari sekolah SMA/SMK dengan nilai ujian diatas 70 mengambil jurusan TI, sedangkan mahasiswa baru yang berasal dari sekolah SMK dengan nilai ujian dibawah 70 dan SMA dengan nilai ujian dibawah 50 mengambil jurusan SI, dan sisanya mengambil jurusan NON TI/SI.

3. Kualiatas cluster yang dihasilkan berdasarkan proses pengujian yang dilakukan didapatkan hasil nilai Silhouette Coefficient terbaik yaitu 0.690754 dengan jumlah cluster 3 dan jumlah data 15. Berdasarkan hasil tersebut dapat diambil kesimpulan bahwa jumlah cluster dan jumlah data mempengaruhi terhadap hasil kualitas dari cluster.

\section{Saran}

Saran penulisan terkait penelitian "Implementasi Metode K-Medoids Clustering Untuk Mengetahui Pola Pemilihan Program Studi Mahasiswa Baru di Universitas Kanjuruhan Malang” untuk penelitian selanjutnya sebagai berikut:

1. Dianjurkan melakukan penambahan jumlah data dan paramater, dimana dalam penentuan parameter dilakukan peninjauan ulang dengan menggunakan bantuan sebuah algoritma atau dengan bantuan para ahli untuk prosedur pemilihan parameter, sehingga tingkat kualitas cluster yang dihasilkan lebih baik.

2. Penelitian selanjutnya dapat mengembangkan perangkat lunak dengan menggunakan metode clustering lain, seperti metode DBSCAN untuk dapat membandingkan nilai kualitas cluster yang terbentuk dengan hasil dari penelitian sebelumnya.

\section{DAFTAR PUSTAKA}

Andre. 2014. Tutorial Belajar CSS: Cara Mengatur Tinggi Baris dalam Paragraf HTML (lineheight), (Online), (https://www.duniailkom.com/tutorial-belajar-css-cara-mengaturtinggi-baris-dalam-paragraf-html-line-height/), diakses 22 Januari 2019.

Chrisnanto, Yulison H. \& Abdillah, G. 2015. Penerapan Algoritma Partitioning Around Medoids (PAM) Clustering Untuk Melihat Gambaran Umum Kemampuan Akademik Mahasiswa. Seminar Nasional Teknologi Informasi dan Komunikasi, (Online), 15 (1): 444-448, (https://fti.uajy.ac.id/sentika/publikasi/makalah/2015/56.pdf), diakses 21 Maret 2018.

Defiyanti, Sofi., Jajuli, Mohamad, \& Nurul R. W. 2017. Optimalisasi K-Medoid Dalam Pengklasteran Pelamar Beasiswa Dengan Cubic Clustering Criterion, Teknosi, (Online), 17(01): 211-218, (http://teknosi.fti.unand.ac.id/index.php/teknosi/article/view/222), diakses 30 Januari 2019.

Han, J., Pei, J., and Kamber, M. 2011. Data Mining: Concepts and Techniques. Third Edition, Morgan Kaufman.

Irwansyah, E., and Faisal M. 2015. Advanced Clustering Teori dan Aplikasi. Yogyakarta: DeePublish.

Irwansyah, Edy, $\quad$ S.T., $\quad$ M.SI. 2017. Clustering, (Online), (http://socs.binus.ac.id/2017/03/09/clustering/), diakses pada 7 Februari 2019.

Kadir, Abdul. 2017. Dasar Logika Pemrograman Komputer. Jakarta: Elex Media Komputindo

Kaur, Noor K., Kaur, Usvir. \& Singh, Dr. Dheerendra. 2014. K-Medoid Clustering Algorithm- A Review, International Journal of Computer Application and Technology, (Online), 14 (1): 
42-45, (https://www.academia.edu/8446443/K-Medoid_Clustering_AlgorithmA_Review?auto=download), diakses 22 Maret 2018.

Kusrini, and Luthfi E.T. 2009. Algoritma Data Mining. Yogyakarta: Andi.

Larose, Daniel, T. and Larose, Chantal D. 2015. Data Mining and Predictive Analytics. Second Edition, John Wiley \& Sons.

Pramesti, Dyang F., Furqon M. Tanzil, \& Dewi, C. 2017. Implementasi Metode K-Medoids Clustering Untuk Pengelompokan Data Potensi Kebakaran Hutan/Lahan Berdasarkan Persebaran Titik Panas (Hotspot), Jurnal Pengembangan Teknologi Informasi dan Ilmu Komputer, (Online), $17 \quad$ (9): 723-732, (http://j-ptiik.ub.ac.id/index.php/jptiik/article/download/204/101/), diakses 23 Februari 2018.

Solichin, Ahmad. 2016. Pemrograman Web dengan PHP dan MySQL. Jakarta: Universitas Budi Luhur. 